\title{
PENGARUH FRAUD TRIANGLE SEBAGAI PREDIKTOR KECURANGAN PELAPORAN KEUANGAN
}

\author{
MIA TRI PUSPITANINGRUM \\ EINDYE TAUFIQ \\ SATRIA YUDHIA WIJAYA
}
Universitas Pembangunan Nasional Veteran Jakarta, JI. RS Fatmawati, Pd. Labu, Cilandak, Kota Depok, Daerah Khusus Ibukota Jakarta 12450, Indonesia
miatripuspita@gmail.com

\begin{abstract}
The purpose of this study is to examine Influence of external pressure, effective monitoring, and rationalitation to financial fraudulent reporting. The sample used in this study is real estate, property, and building construction companies listed on the Indonesia Stock Exchange (BEI) in the period 2016-2017. By using purposive sampling method, it is obtained as many as 57 real-estate, property, and building construction companies as the study sample. The method of analysis used in this study is logistic regression. In this research also include the overall fit model test, hosmer and lemeshow's test, goodness of fit test, and classification matrix. Results of this study indicate that the effective monitoring and rationalitation are not significant to financial fraudulent reporting, while external pressure is significant to financial fraudulent reporting.
\end{abstract}

Keywords: External pressure, effective monitoring, rationalitation, financial fraudulent reporting

Abstrak: Tujuan penelitian adalah untuk menguji pengaruh tekanan eksternal, pemantauan yang efektif, dan rasionalisasi terhadap pelaporan kecurangan keuangan. Sampel yang digunakan dalam penelitian ini adalah perusahaan real estat, properti, dan konstruksi bangunan yang terdaftar di Bursa Efek Indonesia (BEI) pada periode 2016-2017. Dengan menggunakan metode purposive sampling, diperoleh sebanyak 57 perusahaan real estat, properti, dan konstruksi bangunan sebagai sampel penelitian. Metode analisis yang digunakan dalam penelitian ini adalah regresi logistik. Dalam penelitian ini juga termasuk uji model fit keseluruhan, tes hosmer dan lemeshow, uji goodness of fit, dan matriks klasifikasi. Hasil penelitian ini menunjukkan bahwa pemantauan dan rasionalisasi yang efektif tidak signifikan terhadap pelaporan kecurangan keuangan, sedangkan tekanan eksternal signifikan terhadap pelaporan kecurangan keuangan.

Kata kunci: Tekanan eksternal, pemantauan yang efektif, rasionalisasi, pelaporan kecurangan keuangan

\section{PENDAHULUAN}

Laporan keuangan merupakan hasil akhir dari siklus akuntansi. Laporan keuangan adalah cerminan kondisi perusahaan di dalam suatu kurun waktu tertentu.Laporan keuangan disusun berdasarkan Standar Akuntansi
Keuangan (SAK) yang telah ditetapkan oleh Ikatan Akuntan Indonesia (IAI). Penyataan Standar Akuntansi Keuangan (PSAK) No.1 (2015) menyebutkan tujuan laporan keuangan adalah menunjukkan kinerja manajemen atau pertanggungjawaban manajemen terhadap sumber daya yang dipercayakan kepada pihak 
manajemen. Pengguna laporan keuangan dalam hal ini adalah investor. Investor menilai kinerja atau pertanggungjawaban manajemen sehingga pemilik modal bisa membuat keputusan ekonomi untuk menahan atau menjual investasi yang terdapat di perusahaan.

Saat laporan keuangan terbit, manajemen menginginkan laporan keuangan tersebut menggambarkan kondisi perusahaan dalam keadaan yang terbaik agar para stakeholder menilai baik kinerja manajemen. Tidak jarang manajemen sampai melakukan manipulasi laporan keuangan sesuai yang mereka inginkan. Hal ini mengakibatkan informasi yang terkandung di dalam laporan keuangan tersebut menjadi tidak benar. Informasi tersebut tentu saja menjadi informasi yang tidak valid atau tidak relevan untuk dipakai sebagai dasar di dalam pengambilan keputusan oleh pihak yang berkepentingan karena analisis yang dilakukan tidak berdasarkan informasi yang sebenarnya.

Kecurangan pelaporan keuangan merupakan kesalahpahaman yang disengaja dari kondisi keuangan suatu perusahaan dengan melakukan salah saji yang disengaja atau kelalaian terhadap jumlah atau pengungkapan dalam laporan keuangan untuk menipu pengguna laporan keuangan (ACFE, 2015). Kasus lainnya yang terjadi di Indonesia, yaitu PT Waskita Karya (Persero). Pada tahun 2009 ditemukan kasus kelebihan pencatatan pada laporan keuangan periode 2004-2007. Terbongkarnya kasus ini berawal saat pemeriksaan kembali neraca dalam rangka penerbitan saham perdana tahun lalu.Direktur Utama baru, M. Choliq yang sebelumnya menjabat Direktur Keuangan PT Adhi Karya (Persero) Tbk, menemukan pencatatan yang tak sesuai. Dalam pemeriksaan itu ditemukan kelebihan pencatatan laba bersih sekitar Rp 400 miliar. Akibatnya penawaran saham Waskita ditunda hingga PT Perusahaan Pengelola Aset (Persero) menyelesaikan restrukturisasi yang diperkirakan memakan waktu dua tahun dan penonaktifkan tiga direksi PT Waskita Karya (Persero) oleh Kementerian Negara Badan Usaha Milik Negara (BUMN) (Rahadiana, 2009).

Dari kasus tersebut terjadi perbedaan pencatatan laba pada laporan keuangan dengan laba yang sebenarnya sehingga mengindikasikan pemanipulasian laporan keuangan keuangan. Tindakan pemanipulasian laporan keuangan ini adalah salah satu bentuk tindakan kecurangan. Pelaporan keuangan yang mengandung kecurangan biasanya dilakukan dengan cara kesalahan yang berkaitan dengan jumlah, klasifikasi, penyajian, atau pengungkapan (Hery, 2017, hlm.198).

Asosiasi Nasional Profesi Akuntan Publik di Amerika Serikat atau American Institute Certified Public Accountant (AICPA) memberikan solusi dalam prosedur pendeteksian kecurangan dengan menerbitkan Statement of Auditing Standards (SAS). SAS No. 99 menyebutkan ilustrasi faktor kecurangan yang didasarkan pada teori segitiga kecurangan atau fraud triangle yang dicetuskan oleh Donald.R.Cressey pada tahun 1953, yaitu tekanan, peluang, dan rasionalisasi.

Institut Akuntan Publik Indonesia (IAPI) yang merupakan asosiasi profesi akuntan publik Indonesia juga mengeluarkan Standar Audit (SA) 240 pada tahun 2013 yang berisi tentang tanggung jawab auditor terkait dengan kecurangan dalam suatu audit atas laporan keuangan. SA 240 juga berisi ilustrasi faktor kecurangan yang didasarkan pada fraud triangle yang dicetuskan oleh Donald R. Cressey.

Salah satu kondisi (jenis) tekanan mungkin mengakibatkan terjadinya kecurangan pelaporan keuangan yang disebutkan dalam Standar Audit 240 (2013) adalah tekanan eksternal. Tekanan eksternal adalah adanya tekanan yang dihadapi manajemen untuk memenuhi persyaratan atau harapan dari pihak ketiga. Hasil penelitian yang dilakukan oleh Lou \& Wang (2009), Utama et al.(2018), Zaki (2017) 
serta Yesiriani dan Rahayu (2017) menunjukkan bahwa tekanan eksternal berpengaruh signifikan terhadap kecurangan pelaporan keuangan. Sebaliknya penelitian yang dilakukan oleh Ardiyani \& Utaminingsih (2015), Martantya dan Daljono (2013), serta Rachmawati dan Marsono (2014) menunjukkan bahwa tekanan eksternal tidak berpengaruh signifikan terhadap kecurangan pelaporan keuangan.

Salah satu kondisi (jenis) peluang mungkin mengakibatkan terjadinya kecurangan pelaporan keuangan yang disebutkan dalam Standar Audit 240 (2013) adalah efektivitas pemantauan. Hasil penelitian yang dilakukan oleh Utomo (2018) menunjukkan bahwa efektivitas pemantauan berpengaruh signifikan terhadap kecurangan pelaporan keuangan. Sebaliknya penelitian yang dilakukan oleh Rachmawati dan Marsono (2014) serta Martantya dan Daljono (2013) menunjukkan efektivitas pemantauan tidak berpengaruh signifikan terhadap kecurangan pelaporan keuangan.

Rasionalisasi adalah suatu perilaku atau karakter yang membuat pelaku melakukan tindakan yang tidak jujur, atau lingkungan yang membuat mereka menjadi bertindak tidak jujur dan membenarkan tindakan tidak jujur tersebut. Hasil penelitian yang dilakukan oleh Utama et al. (2018) serta Rachmawati dan Marsono (2014) menunjukkan bahwa rasionalisasi berpengaruh signifikan terhadap kecurangan pelaporan keuangan. Sebaliknya penelitian yang dilakukan oleh Apriliana dan Agustina (2017), Tessa dan Harto (2016), dan Rahmawati et al. (2017) menunjukkan rasionalisasi tidak berpengaruh signifikan terhadap kecurangan pelaporan keuangan.

Tujuan dari dilakukannya penelitian ini adalah untuk membuktikan pengaruh tekanan eksternal, efektivitas pemantauan, dan rasionalisasi terhadap kemungkinan terjadinya kecurangan pelaporan keuangan.

\section{Teori Keagenan}

Teori keagenan mendeskripsikan hubungan antara pemegang saham (shareholders) sebagai prinsipal dan manajemen sebagai agen. Jensen dan Meckling (1976) mendefinisikan bahwa hubungan agensi merupakan sebagai kontrak di mana satu atau lebih pihak prinsipal (principal) dengan melibatkan pihak lain agen (agent) untuk melakukan beberapa jasa atas nama mereka yang melibatkan pendelegasian beberapa otoritas pengambilan keputusan kepada agen. Manajemen merupakan pihak yang dikontrak oleh pemegang saham untuk bekerja demi kepentingan para pemegang saham.

Menurut Scott (2012, p.340) teori agensi mempelajari desain kontrak untuk memotivasi agen untuk bertindak atas nama principal ketika kepentingan agen tidak bertentangan dengan kepentingan principal. Ketika kepentingan agen bertentangan dengan kepentingan principal maka akan terjadi conflict of interest. Hal tersebut terjadi karena pada dasarnya kedua pihak akan bertindak untuk kepentingan diri mereka sendiri.

Konflik tersebut dapat memicu terjadinya asimetri informasi di antara kedua belah pihak tersebut. Agen sebagai pihak internal memiliki informasi yang lebih banyak jika dibandingkan dengan principal dikarenakan agen bertanggung jawab terhadap segala sesuatu yang berhubungan dengan perusahaan. Hal ini dimanfaatkan oleh agen untuk menyembunyikan informasi bagi principal. Informasi yang dianggap manajer tidak perlu untuk diketahui oleh pihak principal dapat disembunyikan oleh agen untuk tujuan tertentu. Keadaan ini dapat mendorong seorang manajer untuk melakukan kecurangan

\section{Kecurangan}

Menurut Association of Certified Fraud Examiner (ACFE) (2018) kecurangan adalah mengetahui salah saji dari kebenaran atau penyembunyian sebuah fakta material untuk 
menyebabkan kerugian pihak lain. SA 240 (2013) menyebutkan bahwa kecurangan merupakan suatu tindakan yang disengaja oleh satu individu atau beberapa individu dalam manajemen, pihak yang bertanggung jawab atas tata kelola, karyawan, atau pihak ketiga, dan melibatkan penggunaan tipu muslihat untuk memperoleh suatu keuntungan secara tidak adil atau melanggar hukum. Dapat dikatakan kecurangan adalah tindakan disengaja menyembunyikan fakta dengan tipu muslihat dari suatu hal yang dilakukan dengan tujuan untuk merugikan pihak lain.

ACFE dikutip dari Priantara $(2013, \mathrm{hlm}$. 67) mengembangkan model untuk mengelompokkan fraud yang disebut dengan fraud tree. Fraud tree merupakan cara menyajikan klasifikasi atau taksonomi dari berbagai bentuk fraud. Fraud tree mempunyai tiga cabang utama dan banyak ranting pada setiap cabangnya. Tiga cabang utama tersebut adalah korupsi (corruption), kecurangan terhadap aset (asset misappropriation), dan laporan yang dimanipulasi (fraudulent statement) dikutip dari Priantara (2013, hlm. 68)

1. Penyimpangan atas aset(asset misappropriation)

Penyimpangan atas aset, yaitu penyalahgunaan, penggelapan, atas pencurian aset atau harta perusahaan oleh pihak di dalam dan/atau di luar perusahaan

2. Pernyataan atau pelaporan yang menipu atau dibuat salah (fraudulent statement)

Kecurangan laporan keuangan meliputi tindakan yang dilakukan oleh pejabat atau eksekutif dan manajer senior suatu perusahaan atau instansi pemerintah untuk menutupi kondisi keuangan yang sebenarnya dengan melakukan rekayasa keuangan atau mempercantik penyajian laporan keuangan guna memperoleh keuntungan atau manfaat pribadi mereka terkait dengan kedudukan dan tanggung jawabnya.

\section{Korupsi (corruption)}

Jenis kecurangan korupsi paling sulit dideteksi sebab menyangkut kerja sama dengan pihak lain. Kecurangan jenis ini sering kali tidak dapat dideteksi karena para pihak yang bekerja sama saling menikmati keuntungan (simbiosis mutualisma). Jenis kecurangan yang termasuk korupsi, yaitu penyalahgunaan wewenang atau konflik kepentingan (conflict of interest), penyuapan (bribery), penerimaan tidak sah/legal (illegal gratuities) yang lebih dikenal sebagai hadiah dan gratifikasi yang terkait dengan hubungan kerja dan jabatan, dan pemerasan secara ekonomi (economic extortion) atau dikenal sebagai pungutan liar atau upeti.

\section{Segitiga Kecurangan}

Teori ini dicetuskan oleh Donald $\mathrm{R}$. Cressey pada tahun 1953. Cressey melakukan penelitian ekstensif dengan para pelaku kejahatan yang terbukti bersalah untuk menentukan apa yang memotivasi orang tampaknya jujur untuk melakukan penipuan. Temuan Cressey ini akhirnya diringkas dengan sebutan fraud triangle. Tiga komponen dari fraud triangle adalah tekanan, peluang, dan rasionalisasi. Ketiga komponen yang dicetuskan oleh Cressey dalam Priantara (2013, hlm. 44) sebagai berikut:

1. Sisi pertama adalah tekanan (pressure). Tekanan adalah dorongan untuk melakukan kecurangan. Biasanya tekanan muncul karena kebutuhan atau masalah finansial, tetapi banyak juga pelaku yang hanya terdorong oleh keserakahan.

2. Sudut kedua adalah peluang atau opportunity. Opportunity adalah peluang yang memungkinkan terjadinya kecurangan. Pada dasarnya ada dua faktor yang dapat meningkatkan adanya peluang atau kesempatan seseorang yang melakukan kecurangan, yaitu: 
a. Sistem pengendalian internal yang lemah, seperti kurang atau tidak ada audit trail (jejak audit) sehingga tidak dapat dilakukan penelusuran, ketidakcukupan, dan ketidakefektifan aktivitas pengendalian pada area dan proses bisnis yang berisiko, sistem dan kompetensi sumber daya manusia (SDM) tidak mengimbangi kompleksitas organisasi, kebijakan dan prosedur SDM yang kurang kondusif.

b. Tata kelola organisasi buruk dapat meningkatkan adanya peluang melakukan kecurangan. Hal itu seperti tidak ada komitmen yang tinggi dan suri tauladan yang baik dari lapisan manajemen, sikap manajemen yang lalai.

3. Sisi ketiga adalah rasionalisasi. Rasionalisasi terjadi karena seseorang mencari pembenaran atas aktivitasnya yang mengandung kecurangan. Para pelaku kecurangan meyakini atau merasa bahwa tindakannya bukan merupakan suatu kecurangan tetapi merupakan sesuatu yang merupakan haknya, bahkan terkadang pelaku telah merasa berjasa karena telah berbuat banyak untuk organisasi.

\section{Kecurangan Pelaporan Keuangan}

Association of Certified Fraud Examiner (ACFE) (2015) menyatakan bahwa kecurangan pelaporan keuangan adalah kesalahpahaman yang disengaja dari kondisi keuangan suatu perusahaan dengan melakukan salah saji yang disengaja atau kelalaian terhadap jumlah atau pengungkapan dalam laporan keuangan untuk menipu pengguna laporan keuangan. Pelaporan keuangan yang mengandung kecurangan mencakup kesalahan penyajian yang disengaja termasuk penghilangan suatu jumlah atau pengungkapan dalam laporan keuangan yang dilakukan untukmempengaruhi persepsi para pengguna laporan keuangan (SA 240, 2013). Dapat dikatakan kecurangan pelaporan keuangan merupakan kesalahan yang disengaja dengan melakukan salah saji jumlah atau pengungkapan dalam penyajian laporan keuangan untuk mendapatkan keuantungan dari pihak lain.

Dikutip dari Hery (2017, hlm. 198) pelaporan keuangan yang mengandung kecurangan biasanya dilakukan dengan cara sebagai berikut:

1. Manipulasi, pemalsuan, atau mengubah catatan akuntansi atau dokumen pendukung yang menjadi dasar penyusunan lapoan keuangan.

2. Kesalahan pengungkapan atau penghilangan secara sengaja peristiwa, transaksi, atau informasi signifikan lain dalam laporan keuangan.

3. Kesalahan yang disengaja atas penerapan prinsip akuntansi, khususnya yang berkaitan dengan jumlah, klasifikasi, penyajian, atau pengungkapan.

Hipotesis yang diajukan:

$\mathrm{H}_{1}$ : Tekanan eksternal berpengaruh signifikan terhadap kemungkinan terjadinya kecurangan pelaporan keuangan.

$\mathrm{H}_{2}$ : Efektivitas pemantauan berpengaruh signifikan terhadap kemungkinan terjadinya kecurangan pelaporan keuangan.

$\mathrm{H}_{3}$ : Rasionalisasi berpengaruh signifikan terhadap kemungkinan terjadinya kecurangan pelaporan keuangan.

\section{METODA}

Populasi yang digunakan dalam penelitian ini adalah perusahaan real estate, property, dan building construction yang terdaftar di Bursa Efek Indonesia (BEI). Penelitian ini membatasi populasi dengan menggunakan teknik purposive sampling, yaitu (1) Perusahaan real estate, property, dan building construction yang sudah go public atau terdaftar di Bursa Efek Indonesia (BEI) selama periode 2016-2017; (2) Perusahaan real estate, property, dan building construction yang mempublikasikan laporan keuangan tahunan yang telah diaudit dan annual report dalam 
website perusahaan atau website BEI selama periode 2016-2017; (3) Data mengenai variabel penelitian secara keseluruhan tersedia dan terpublikasi selama periode 2016-2017. Berdasarkan hasil dari pemilihan sampel dengan kriteria tertentu, sampel dalam penelitian ini sebanyak 57 perusahaan. Jumlah sampel dalam penelitian ini sebanyak 114 sampel. Sumber data yang diperoleh untuk penelitian ini, yaitu laporan keuangan yang telah diaudit oleh auditor independen dan annual report pada perusahaan real estate, property, dan building construction tahun 2016-2017 yang diperoleh melalui situs web Bursa Efek Indonesia (BEI) www.idx.co.id dan situs resmi masing-masing perusahaan. Prosedur yang dilakukan dengan menggunakan bantuan program komputer yaitu SPSS 25 (Statistical Product and Service Solutions) dan Microsoft Office Excel.

Tabel 1 Variabel Penelitian

\begin{tabular}{|c|c|c|}
\hline Variabel & Definisi Operasional & Pengukuran Variabel \\
\hline $\begin{array}{l}\text { Kecurangan } \\
\text { Pelaporan } \\
\text { Keuangan }\end{array}$ & $\begin{array}{lr}\text { Kecurangan } & \text { laporan } \\
\text { keuangan merupakan } & \text { mang } \\
\text { kesalahpahaman yang } & \text { disengaja dari kondisi } \\
\text { keuangan } & \text { suatu } \\
\text { perusahaan dengan } & \text { delakukan salah saji } \\
\text { yang disengaja atau } \\
\text { kelalaian terhadap } \\
\text { jumlah datam } \\
\text { pengungkapan dalam } \\
\text { laporan keuangan untuk } \\
\text { menipu pengguna } \\
\text { laporan keuangan (ACFE } \\
\text { 2015). }\end{array}$ & $\begin{array}{l}\text { Diukur dengan menggunakan model } \\
\text { Beneish M-Score. Beneish M-Score } \\
\text { diukur dengan menggunakan } 8 \text { (delapan) } \\
\text { rasio keuangan. Jika Beneish M-Score } \\
\text { lebih besar dari -2.22, diindikasikan } \\
\text { sebagai perusahaan yang melakukan } \\
\text { fraud dan diberi kode } 1 \text {. Sebaliknya jika } \\
\text { skor lebih kecil dari }-2.22 \text {, diindikasikan } \\
\text { sebagai perusahaan yang tidak } \\
\text { melakukan fraud dan diberi kode } 0\end{array}$ \\
\hline Tekanan eksternal & 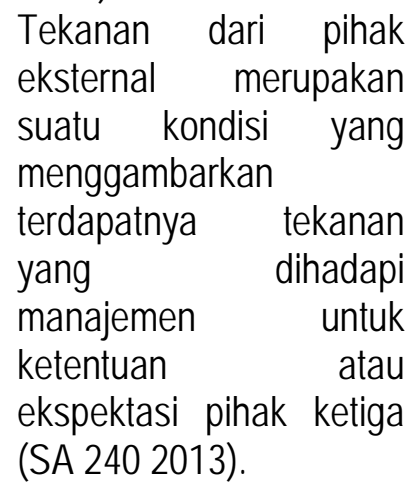 & $\begin{array}{l}\text { Rasio Leverage } \\
L E V=\frac{\text { total utang }}{\text { total aset }}\end{array}$ \\
\hline $\begin{array}{l}\text { Efektivitas } \\
\text { Pemantauan }\end{array}$ & $\begin{array}{l}\text { Kegiatan pengawasan } \\
\text { mencakup pemeriksaan } \\
\text { apakah rencana yang }\end{array}$ & Rasio Komisaris Independen \\
\hline
\end{tabular}




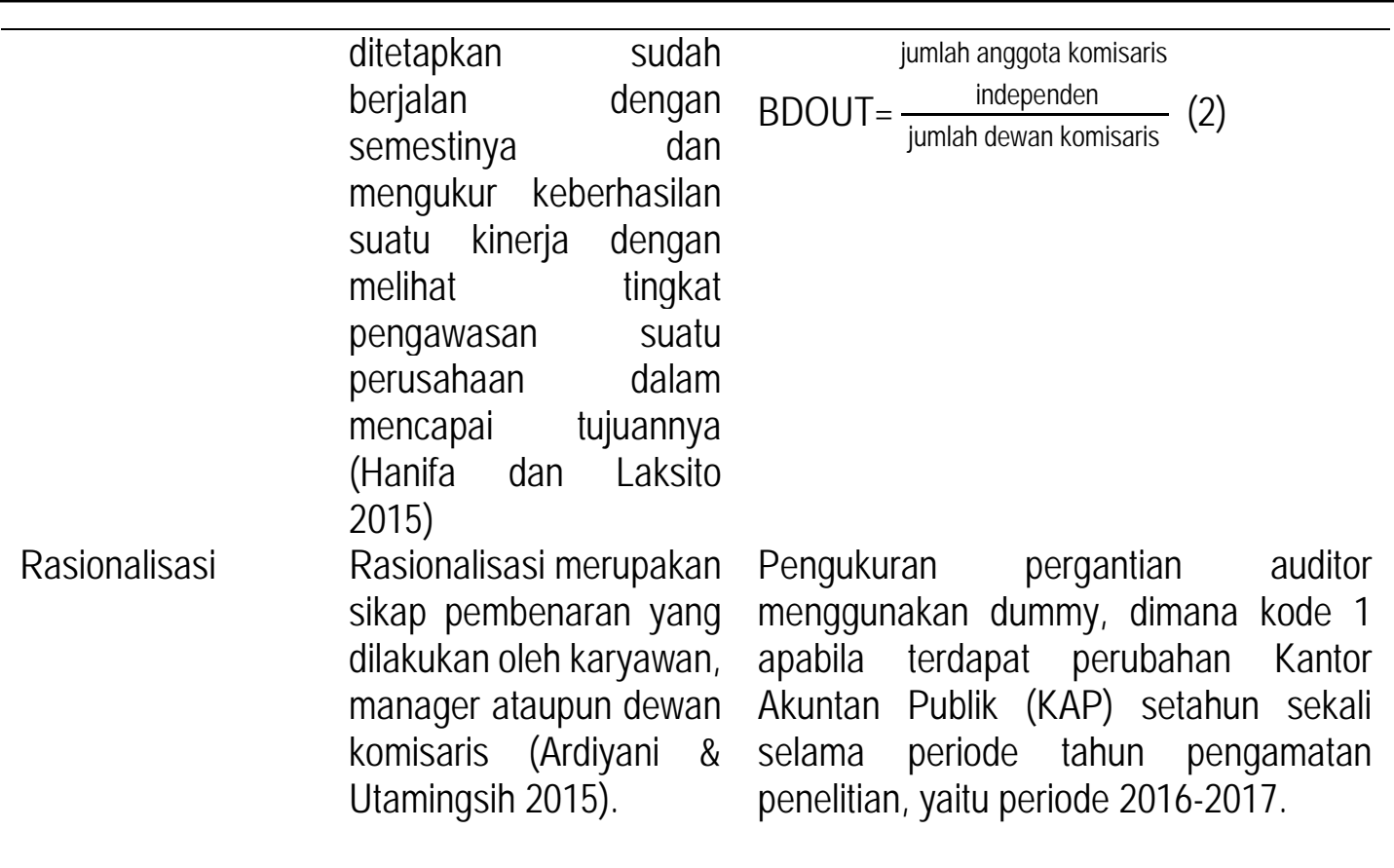

Beneish M-Score, kecurangan pelaporan keuangan akan diukur menggunakan indeks yang dikeluarkan oleh Beneish pada tahun 1999 dan mengalami perkembangan sampai dengan tahun 2012. Beneish M-score terdiri dari 8 rasio keuangan. Rumus Beneish M-score sebagai berikut:

M-Score $=-4.84+0.920 \mathrm{DSRI}+0.528 \mathrm{GMI}+$ $0.404 \mathrm{AQI}+0.892 \mathrm{SGI}+0.11 \mathrm{DEPI}-$ $0.172 \mathrm{SGAI}+4.679 \mathrm{TATA}-0.327 \mathrm{LEVI}$ (3)

Days' Sales in Receivable Index (DSRI), rasio ini digunakan untuk mengukur rasio hari penjualan dalam bentuk piutang dalam satu tahun berjalan dibandingkan dengan tahun sebelumnya.

DSRI $=\frac{\text { (Account Receivables } \mathrm{t} / \text { Sales } \mathrm{t} \text { ) }}{\text { (Account Receivables } \mathrm{t}-1 \text { / Sales } \mathrm{t}-1)}$

Gross Margin Index (GMI), rasio ini digunakan untuk mengukur rasio laba kotor tahun sebelumnya dibandingkan dengan tahun berjalan.

$\mathrm{GMI}=\frac{(\text { Sales t }-1-\text { COGS t }-1) / \text { Sales t }-1}{(\text { Sales } \mathrm{t}-\text { COGS } \mathrm{t}) / \text { Sales } \mathrm{t}}$
Asset Quality Index (AQI), rasio ini merefleksikan perubahan risiko realisasi aset dengan membandingkan aset lancar, bangunan, tanah dan perlengkapan dengan total aset.

$A Q I=\frac{(1-((\text { Current Asset } t+\text { PPE } t) / \text { Total Asset } t))}{(1-((\text { Current Asset } t-1+P P E t-1) / \text { Total Asset } t-1))}$

Sales Growth Index (SGI), rasio ini digunakan untuk mengukur pertumbuhan pendapatan pada tahun berjalan dibandingkan dengan tahun sebelumnya

$\mathrm{SGI}=\frac{\text { Sales } \mathrm{t}}{\text { Sales } \mathrm{t}-1}$

Depreciation Index (DEPI), rasio ini digunakan untuk mengukur biaya depresiasi dan nilai bangunan, tanah dan perlengkapan pada tahun berjalan dengan tahun sebelumnya.

$\mathrm{EPI}=\frac{(\text { Depreciation } \mathrm{t}-1 / \text { (Depreciation } \mathrm{t}-1+\mathrm{PPE} \mathrm{t}-1))}{(\text { Depreciation } \mathrm{t} /(\text { Depreciation } \mathrm{t}+\mathrm{PPE} \mathrm{t}))}$ 
Sales, General and Administrative Expenses Index (SGAI), rasio ini digunakan untuk mengukur beban penjualan dan adminstratif terhadap penjualan pada tahun berjalan dibandingkan dengan tahun sebelumnya.

SGAI $=\frac{(\text { SGA expenses t/Sales } t)}{(\text { SGA expenses } t-1 / \text { Sales } t-1)}$

Accruals to Total Assets Index (TATA), rasio ini digunakan untuk mengetahui laba akuntansi yang tidak didukung oleh laba tunai. Leverage Index (LEVI), LEVI digunakan untuk mengukur struktur keuangan perusahaan dan mengukur risiko jangka panjang pada perusahaan tersebut.

Jika hasil dari penghitungan Beneish Mscore melebihi -2,22 maka perusahaan digolongkan terindikasi melakukan kecurangan, sedangkan jika kurang dari -2,22 perusahaan digolongkan tidak terindikasi melakukan kecurangan. Perusahaan yang terindikasi melakukan kecurangan pelaporan keuangan akan diberi kode 1 dan perusahaan yang tidak terindikasi melakukan kecurangan pelaporan keuangan akan diberi kode 0 .

Pengujian tahap hipotesis penelitian ini menggunakan regresi logistik (Logistic Regression). Model regresi logistik yang digunakan dalam penelitian ini dapat dinyatakan dalam persamaan sebagai berikut

Ln $p 1-p=\alpha+\beta L E V+\beta B D O U T+\beta R A T+e$

$\begin{array}{ll}\operatorname{Ln} \frac{p}{1-p} & =\quad \text { kecurangan laporan } \\ \text { keuangan } & \\ \alpha & =\text { konstanta } \\ \beta & =\text { koefisien regresi } \\ \text { LEV } & =\text { tekanan eksternal } \\ \text { BDOUT } & =\text { efektivitas pemantauan } \\ \text { RAT } & =\text { rasionalisasi } \\ \beta_{1} \beta_{2} \beta_{3} \beta_{4} & =\text { Koefisien regresi untuk } \\ \text { masing-masing variabel independen }\end{array}$

\section{HASIL DAN PEMBAHASAN}

Statistik deskriptif variabel independen tekanan eksternal selama tahun 2016-2017 dengan jumlah sampel yang digunakan dalam penelitian ini 114 sampel. Dengan mengacu pada tabel 7, dapat diketahui bahwa tekanan eksternal memiliki nilai terendah sebesar 0.0305 atau 3,05\%, nilai tertinggi sebesar 0.7928 atau $79,28 \%$, rata-rata 0,409283 dan standar deviasi 0,199418 . Efektivitas pemantauan memiliki nilai terendah sebesar 25 , nilai tertinggi sebesar $83,33 \%$, nilai rata-rata sebesar 0,395009 dan standar deviasi sebesar 0,0940319. Sebanyak $75,4 \%$ atau 86 data sampel perusahaan tidak melakukan pergantian KAP. Sebanyak $24,6 \%$ atau 28 data sampel perusahaan melakukan pergantian KAP. Sebanyak 39,5\% atau 45 data sampel perusahaan tidak terindikasi kecurangan pelaporan keuangan yang berarti bahwa 45 data sampel perusahaan tersebut mendapatkan skor Beneish M-score <-2,22. Sebanyak 60,5\% atau 69 data sampel perusahaan terindikasi kecurangan pelaporan keuangan yang berarti 69 data sampel perusahaan tersebut mendapatkan skor Beneish M-score >-2,22.

Terdapat perbedaan nilai $-2 \log$ Likelihood saat awal model hanya konstanta (block number= 0) dan nilai -2Log Likelihood saat variabel dimasukkan ke dalam model (block number= 1). Penurunan nilai tersebut dapat dilihat signifikan atau tidak dengan membandingkan angka tersebut dengan angka chi square tabel $(\alpha=5 \%$ dan $d f=3)$ dengan chi square hitung. 9,669 > 7,815 dapat dikatakan chi square hitung $>$ chi square tabel. Penambahan variabel tekanan eksternal, efektivitas pemantauan, dan rasionalisasi ke dalam model memperbaiki model fit.

Nilai Hosmer and Lemeshow lebih besar dari 0,05 , maka hipotesis nol tidak dapat ditolak dan berarti model mampu memprediksi nilai observasinya atau dapat dikatakan model dapat diterima karena cocok dengan data 
observasinya. Nilai Nagelkerke $R$ square adalah sebesar 0,110 yang berarti variabilitas variabel kecurangan pelaporan keuangan dapat dijelaskan oleh variabel tekanan eksternal, efektivitas pemantauan, dan rasionalisasi sebesar 11,0 persen, sedangkan sisanya sebesar 89 persen dijelaskan oleh variabelvariabel lain di luar model penelitian ini.

Kekuatan prediksi dari model regresi untuk memprediksi kemungkinan perusahaan melakukan kecurangan laporan keuangan adalah sebesar 61,4 persen. Hal ini menunjukkan bahwa dengan menggunakan model regresi tersebut, terdapat sebanyak 45 data sampel perusahaan diprediksi 12 di antaranya atau sebesar 26,7\% tidak melakukan kecurangan laporan selama periode pengamatan. Dengan model regresi tersebut, terdapat sebanyak 69 data sampel perusahaan diprediksi 58 di antaranya atau sebesar 84,1\% melakukan kecurangan laporan keuangan selama periode pengamatan. Pengujian hipotesis regresi logistik dapat dilihat sebagai berikut:.

Tabel 2 Uji Signifikansi Koefisien Regresi

\begin{tabular}{lcccccr}
\hline Variabel & B & S.E. & Wald & df & \multicolumn{1}{l}{ Sig. } & \multicolumn{1}{c}{ Exp(B) } \\
\hline Tekanan_eksternal & 2.083 & 1.035 & 4.049 & 1 & .044 & 8.025 \\
& & & & & & 139.711 \\
Efektivitas_pemant & 4.940 & 2.545 & 3.768 & 1 & .052 & \\
auan & & & & & & .460 \\
Rasionalisasi & -.777 & .493 & 2.479 & 1 & .115 & .175 \\
Konstanta & -1.741 & 1.154 & 2.277 & 1 & .131 & \\
\hline
\end{tabular}

Hasil penelitian variabel tekanan eksternal yang diproksikan dengan leverage (LEV) menunjukkan bahwa terdapat pengaruh signifikan terhadap kemungkinan kecurangan pelaporan keuangan. Hasil penelitan ini sesuai dengan hasil penelitian Lou \& Wang (2009), Utama et al.(2018), Zaki (2017) serta Yesiariani dan Rahayu (2017). Namun tidak sesuai dengan penelitian Ardiyani \& Utaminingsih (2015), Martantya dan Daljono (2013), serta Rachmawati dan Marsono (2014) yang menunjukkan hasil bahwa tekanan eksternal tidak berpengaruh signifikan terhadap kemungkinan kecurangan pelaporan keuangan. Hasil penelitian didasarkan pada pengujian statistik yang angkanya signifikan, yaitu nilai signifikansi sebesar 0,044 atau lebih kecil dari 0,05 .

Hasil penelitian variabel efektivitas pemantauan yang diproksikan dengan rasio komisaris independen menunjukkan bahwa tidak terdapat pengaruh signifikan terhadap kemungkinan kecurangan pelaporan keuangan. Hasil penelitan ini sesuai dengan hasil penelitian Rachmawati dan Marsono (2014) serta Martantya dan Daljono (2013). Namun tidak sesuai dengan penelitian Utomo (2018) yang menunjukkan hasil bahwa efektivitas pemantauan berpengaruh signifikan terhadap kemungkinan kecurangan pelaporan keuangan. Hasil penelitian didasarkan pada pengujian statistik yang angkanya signifikan, yaitu nilai signifikansi sebesar 0,052 atau lebih besar dari 0,05 .

Hasil penelitian variabel rasionalisasi yang diproksikan dengan pergantian Kantor Akuntan Publik (KAP) menunjukkan bahwa tidak terdapat pengaruh signifikan terhadap kemungkinan kecurangan pelaporan keuangan. Hasil penelitan ini sesuai dengan hasil penelitian Apriliana dan Agustina (2017), Tessa dan Harto (2016) serta Rahmawati et al. (2017). Namun 
tidak sesuai dengan penelitian Utama et al. (2018) serta Rachmawati dan Marsono (2014) yang menunjukkan hasil bahwa rasionalisasi berpengaruh signifikan terhadap kemungkinan kecurangan pelaporan keuangan. Hasil penelitian didasarkan pada pengujian statistik yang angkanya signifikan, yaitu nilai signifikansi sebesar 0,115 atau lebih besar dari 0,05.

\section{PENUTUP}

Berdasarkan hasil dari penelitian ini menunjukkan bahwa variabel tekanan kesternal dengan proksi leverage berpengaruh signifikan terhadap kecurangan pelaporan keuangan. Variabel efektivitas pemantauan dengan proksi rasio komisaris independen dan variabel rasionalisasi dengan proksi pergantian Kantor Akuntan Publik (KAP) tidak berpengaruh signifikan terhadap kecurangan pelaporan keuangan. Beberapa perusahaan tidak memiliki data yang dibutuhkan untuk perhitungan rumus Beneish M-score. Selain itu, penelitian ini tidak dapat menerapkan peraturan terbaru mengenai pembatasan jasa audit oleh akuntan publik yang diatur dalam PP No. 20 tahun 2015 dikarenakan jika menerapkan pembatasan jasa audit dalam PP tersebut maka riwayat auditor perusahaan selama 5 tahun ke belakang masih dalam keadaan mengikuti peraturan lama Peraturan Menteri Keuangan Nomor: 17/PMK.01/2008. Peneliti selanjutnya dapat mengembangkan penelitian tentang kecurangan pelaporan keuangan dalam perspektif bentuk lainnya, seperti fraud diamond atau fraud pentagon yang terdapat di Indonesia. Disarankan peneliti selanjutnya dapat menambahkan variabel penelitian lain yang belum digunakan dalam penelitian ini sehingga penelitian selanjutnya dapat mewakili seluruh faktor yang dapat mempengaruhi tentang kecurangan pelaporan keuangan. Disarankan peneliti selanjutnya dapat menambah jumlah sampel kategori perusahaan agar dapat memprediksi kasus financial statement fraud pada kategori perusahaan lain, seperti perusahaan nonkeuangan dan perusahaan keuangan. Selain itu, penelitian selanjutnya juga sebaiknya memperluas periode pengamatan agar dapat lebih menggambarkan financial statement fraud atau kecurangan pelaporan keuangan.

\section{REFERENSI:}

Apriliana, S., \& Agustina, L. 2017. The Analysis of Fraudulent Financial Reporting Determinant through Fraud Pentagon Approach. Jurnal Dinamika Akuntansi, 9(2), 154-165.

Ardiyani, S., \& Sri Utaminingsih, N. 2015. Analisis Determinan Financial Statement Melalui Pendekatan Fraud Triangle. Accounting Analysis Journal, 4.

Association of Certified Fraud Examiner (ACFE). 2015. The Fraud Examiner,Altered Statements: Are More Accounting Frauds on the Horizon?.Diakses pada 01 Oktober 2018, dari http://www.acfe.com/fraud-examiner.aspx?id=4294986529

Association of Certified Fraud Examiner (ACFE). 2018. Fraud Risk Management. Diakses pada 01 Oktober 2018, dari http://www.acfe.com/uploadedFiles/ACFE Website/Content/review/frm/01Intro.pdf

Beneish, M. D. 1997. Detecting GAAP violation: Implications for assessing earnings management among firms with extreme financial performance. Journal of Accounting and Public Policy, 16, 271-309.

Jensen, M. C., \& Meckling, W. H. (1976). Theory of the firm: Managerial behavior, agency costs and ownership structure. Journal of Financial Economics, 2, 305-360 
Hanifa, S. I., \& Laksito, H. 2015. Pengaruh Fraud lindicators Terhadap Fraudulent Financial Statements: Studi Empiris Pada Perusahaan Yang Listed Di Bursa Efek Indonesia (BEI) Tahun 2008-2013. Diponegoro Journal of Accounting, 4, 411-425.

Hery. 2017. Auditing dan Asuransi. Jakarta: Grasindo.

Ikatan Akuntan Indonesia. 2015. Standar Akuntansi Keuangan. Jakarta: Salemba Empat

Institut Akuntan Publik Indonesia. 2013. Standar Audit 240: Tanggung Jawab Auditor Terkait dengan Kecurangan dalam Suatu Audit atas Laporan Keuangan. Jakarta: Salembat Empat.

Lou, Y., \& Wang, M. 2009. Fraud Risk Factor Of The Fraud Triangle Assessing The Likelihood Of Fraudulent Financial Reporting. Journal of Business \& Economics Research, 7, 61-78.

Priantara, D. 2013. Fraud Auditing and Investigation. Jakarta: Mitra Wacana Media

Rachmawati, K. K, \& Marsono. 2014. Pengaruh faktor - faktor dalam perspektif fraud triangle terhadap fraudulent financial reporting (studi kasus pada Perusahaan Berdasarkan Sanksi dari Bapepam Periode 2008-2012). Diponegoro Journal of Accounting, 3

Rahadiana, R. 2009. Tiga Direksi Waskita Dinonaktifkan. Diakses pada 29 Agustus 2018, dari https://bisnis.tempo.co/read/194968/tiga-direksi-waskita-dinonaktifkan

Rahmawati, A. D., Nazar, M. R., \& Triyanto, D. N. 2017. Pengaruh Faktor-Faktor Fraud Triangle Terhadap Financial Statement Fraud ( Studi Pada Perusahaan Sektor Jasa yang Terdaftar di Bursa Efek Indonesia ( BEI ). E-Proceeding of Management, 4, 2715-2722.

Scott, W. R. 2012. Financial Accounting Theory. New Jersey: Prentice Hall, Inc.

Tessa, C., \& Harto, P. 2016. Fraudulent Financial Reporting: Pengujian Teori Fraud Pentagon Pada Sektor Keuangan dan Perbankan di Indonesia. Simposium Nasional Akuntansi XIX, Lampung.

Utama, I. G. P. O. S., Ramantha, I. W., \& Badera, I. D. N. 2018. Analisis Faktor-Faktor Dalam Perspektif Fraud Triangle Sebagai Prediktor Fraudulent Financial Reporting. E-Jurnal Ekonomi Dan Bisnis Universitas Udayana, 7, 251-278.

Utomo, L. P. (2018). Kecurangan Dalam Laporan Keuangan "Menguji Teori Fraud Triangle. Jurnal Akuntansi Dan Pajak, 19, 77-88.

Yesiariani, M., \& Rahayu, I. 2017. Deteksi financial statement fraud: Pengujian dengan fraud diamond. Jurnal Akuntansi \& Auditing Indonesia, 21(1), 49-60.

Zaki, N. M. 2017. The Appropriateness of Fraud Triangle and Diamond Models in Assessing the Likelihood of Fraudulent Financial Statements - An Empirical Study on Firms Listed in the Egyptian Stock Exchange. International Journal of Social Science and Economic Research, 02, 2403-2433. 
